\title{
Online Learning During Pandemic Period: a Challenge, Hope, and Solution
}

\author{
Nise Samudra Sasanti \\ ${ }^{*}$ Program Studi Pendidikan Bahasa Jepang, Universitas Negeri Surabaya \\ e-mail:nisesamudra@unesa.ac.id
}

\begin{abstract}
Emerging of Corona Virus Disease (COVID-19) by the end of 2019 changes the learning system into online learning. All parties are not yet ready to change using different teaching methods and online applications. All institutes, either governmental or private institutes, are demanded to quickly carry out innovations to keep the learning going. On that score, the educators are demanded to start creating changes by prioritizing variety in teaching, by shifting to use internet network. One of the changes is by arranging more interesting and various teaching media to be easily accepted and learned by students at home without using an internet connection. It is done so that it will not add more burden to the students' parents. This research aims to determine the challenges, hopes, and solutions of online learning during the pandemic period. The

Keywords:

Learning; Online; Challenge;

Hope; Solution

Article Info:

First received:

28 July 2021

Available online:

30 November 2021 research instruments in the form of questionnaires shared by using WhatsApp group and emails. The total respondents are 39 students of the Japanese Language Education Program of UNESA which engaged in online learnings. The result of the research showed that there are some challenges faced by respondents, they are; a) online learning burdens them; b) internet connection is the biggest obstacle; and, c) they have not yet mastered information technology (IT). Nevertheless, the respondents hope that a) the learning keeps on going; b). There will be an internet quota as assistance; and, c) the pandemic stops soon. Meanwhile, the solutions they hope for are; a) internet quota assistance; b) empowerment of the educators and also the students.
\end{abstract}

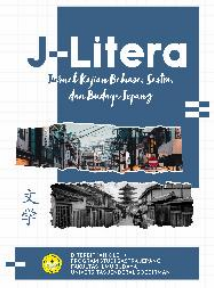

\section{PENDAHULUAN}

Wabah covid-19 yang muncul telah berdampak ke dalam berbagai sendi perekonomian tak terkecuali dunia pendidikan. Adanya wabah yang mudah menular serta mengkhawatirkan membuat pemerintah cepat mengambil sikap antisipasi menyusun dan mendirikan satgas untuk memantau di setiap daerah agar wabah tidak mudah meluas. Yang dilakukan pemerintah tidak hanya pada masyarakat umum, tetapi menyasar juga pada lingkup-lingkup yang lebih sempit seperti lembaga pendidikan. Kebijakan yang diambil pemerintah sejauh ini adalah meliburkan semua sekolah, kantor, serta melarang melakukan kegiatan yang sama dengan sebelum ada wabah. Hal ini didukung oleh Surat Edaran Nomor 4 Tahun 2020 tentang Pelaksanaan Kebijakan Pendidikan Dalam Masa Darurat Penyebaran Coronavirus Disease (Covid-19), ditandatangai oleh Menteri Pendidikan dan Kebudayaan
Nadiem Makarim pada tanggal 24 Maret 2020 (Anugrahana, 2020). Kebijakan yang diambil adalah mewajibkan bagi pendidik, peserta didik, tenaga kependidikan serta keluarganya menjalankan kegiatannya di rumah saja. Oleh sebab itu, semua lembaga pendidikan mau tidak mau, siap tidak siap diharapkan mengubah strategi mengajarnya. Pembelajaran yang awalnya bertatap muka harus diubah dengan pembelajaran tatap mata, yang kemudian dikenal dengan pembelajaran dalam jaringan atau daring. Berkaitan dengan perubahan sistem pembelajaran tersebut membawa dampak pada peserta didik karena peserta didik harus berhadapan dengan hal-hal baru yang tentu memunculkan tantangan, harapan serta jalan keluar atau solusi. Berdasarkan hal di atas, penelitian ini ingin mengetahui tantangan, harapan, dan solusi peserta didik dalam mengikuti proses belajar mengajar di masa pandemi. 


\section{KERANGKA TEORITIS}

\section{Wabah Covid-19}

Wabah COVID-19 pertama kali dideteksi di Kota Wuhan, Hubei, Tiongkok pada tanggal 1 Desember 2019 dan ditetapkan sebagai pandemi oleh Organisasi Kesehatan Dunia (WHO) pada tanggal 11 Maret 2020. Wabah COVID-19 adalah peristiwa menyebarnya penyakit koronavirus 2019 (Coronavirus Disease 2019 atau disingkat COVID-19) di seluruh dunia untuk semua negara.

Virus SARS-CoV-2 diduga menyebar di antara orang-orang terutama melalui percikan pernapasan (droplet) yang dihasilkan selama batuk. Percikan ini juga dapat dihasilkan dari bersin dan pernapasan normal. Selain itu, virus dapat menyebar akibat menyentuh permukaan benda yang terkontaminasi dan kemudian menyentuh wajah seseorang (Wikipedia.org). Terkait dampak penyebaran virus Covid-19 pada dunia pendidikan menuntut para pendidik dan peserta didik untuk mampu dengan cepat beradaptasi dengan perubahan yang ada. Sistem pembelajaran yang semula berbasis pada tatap muka secara langsung di kelas, harus digantikan dengan sistem pembelajaran yang terintegrasi melalui jaringan internet secara virtual (online learning) (Sulia, 2020).

Berdasarkan hasil keputusan Menteri Pendidikan melalui Surat Edaran Nomor 3 Tahun 2020 Tentang Pencegahan Corona Virus Disease bahwa kegiatan pembelajaran baik di sekolah maupun perguruan tinggi diliburkan dan dilaksanakan di rumah masing-masing secara online (Kemdikbud, 2020). Upaya untuk mencegah penyebaran virus corona termasuk pembatasan perjalanan, karantina, pemberlakuan jam malam, penundaan dan pembatalan acara, serta penutupan fasilitas, bahkan sampai sekarang pembatasan tetap dijalankan karena penularannya semakin melonjak seiring adanya libur lebaran dan hari besar lainnya.

\section{Pengertian Pembelajaran daring}

Menurut Saifuddin (Sulia, 2020) Istilah daring merupakan akronim dari "dalam jaringan", yaitu suatu kegiatan yang dilaksanakan dengan sistem daring yang memanfaatkan internet. Menurut Bilfaqih \& Qomarudin dalam (Kamayanthy, 2020) pembelajaran daring merupakan program penyelenggaraan kelas pembelajaran dalam jaringan untuk menjangkau kelompok target yang masif dan luas. Thorme dalam (Kuntarto, 2017) menyatakan, pembelajaran daring adalah pembelajaran yang menggunakan teknologi multimedia, kelas virtual, CD ROM, streaming video, pesan suara, email, telepon konferensi, teks online animasi, dan video streaming online. Sementara itu Rosenberg dalam (Alimuddin. Tawany Rahamma, 2015) menekankan bahwa e-learning merujuk pada penggunaan teknologi internet untuk mengirimkan serangkaian solusi yang dapat meningkatkan pengetahuan dan keterampilan.

Pembelajaran daring sudah diperkenalkan di Indonesia khususnya dalam dunia pendidikan sejak tahun 2014 yang dikenal dengan nama SPADA yaitu Sistem Pembelajaran Daring Indonesia, dengan maksud meningkatkan kemampuan pendidikan tinggi untuk memenuhi tantangan dunia pendidikan yang semakin maju (Surahman, 2020). Pembelajaran daring yang sudah diperkenalkan itu tidak serta merta menjadi familiar bagi perguruan tinggi karena tercatat baru beberapa PT yang menyelenggarakannya. Ketika pandemi masuk barulah SPADA mulai banyak digunakan karena pemerintah memberikan aturan dengan mengadakan SFH (School From Home) bagi semua Sekolah, dari jenjang PAUD hingga PT serta WFH (Work From Home) bagi kantor dan sektor swasta.

Adanya SFH dan WFH mewajibkan lembaga pendidikan menjalankan pembelajaran jarak jauh. Hal inilah yang membuat pendidik siap tidak siap harus mencari solusi agar pembelajaran tetap berjalan dengan baik. Hal itu menyebabkan timbulnya beberapa tantangan, harapan juga solusi. Seperti yang dinyatakan oleh Ali Sadikin dalam (Surahman, 2020) bahwa kelemahan pembelajaran daring, yakni mahasiswa tidak terawasi dengan baik selama proses pembelajaran, lemahnya sinyal internet, dan mahalnya biaya kuota internet.

Menurut Hanum dalam (Anugrahana, 2020) pembelajaran daring atau e-learning adalah salah satu bentuk model pembelajaran yang difasilitasi dan didukung pemanfaatan teknologi informasi dan komunikasi. E-learning dapat didefinisikan sebagai sebuah bentuk teknologi informasi yang diterapkan di bidang pendidikan dalam bentuk dunia maya. Perkuliahan online atau yang biasa 
disebut daring merupakan salah satu bentuk pemanfaatan internet yang dapat meningkatkan peran mahasiswa dalam proses pembelajaran.

\section{Manfaat Pembelajaran Daring (e-Learning)}

Bilfaqih dan Qomarudin dalam (Kamayanthy, 2020) menjelaskan beberapa manfaat dari pembelajaran daring sebagai berikut :

1) Meningkatkan mutu pendidikan dan pelatihan dengan memanfaatkan multimedia secara efektif dalam pembelajaran;

2) Meningkatkan keterjangkauan pendidikan dan pelatihan yang bermutu melalui penyelenggaraan pembelajaran dalam jaringan;

3) Menekan biaya penyelenggaraan pendidikan dan pelatihan yang bermutu melalui pemanfaatan sumber daya bersama.

\section{Ciri-ciri Pembelajaran Daring}

Menurut Peraturan Menteri Pendidikan dan Kebudayaan (PERMENDIKBUD) nomor 109 tahun 2013, ciri-ciri dari pembelajaran daring adalah

1) Pendidikan jarak jauh adalah proses belajar mengajar yang dilakukan secara jarak jauh melalui penggunaan berbagai media komunikasi;

2) Proses pembelajaran dilakukan secara elektronik (e-learning), dimana memanfaatkan paket informasi berbasis teknologi informasi dan komunikasi untuk kepentingan pembelajaran yang dapat diakses oleh peserta didik kapan saja dan dimana saja;

3) Sumber belajar adalah bahan ajar dan berbagai informasi dikembangkan dan dikemas dalam bentuk yang berbasis teknologi informasi dan komunikasi serta digunakan dalam proses pembelajaran;

4) Pendidikan jarak jauh memiliki karakteristik bersifat terbuka, belajar, mandiri, belajar tuntas, menggunakan teknlogi informasi dan komunikasi, menggunakan teknologi pendidikan lainnya, dan berbentuk pembelajaran terpadu perguruan tinggi;

5) Pendidikan jarak jauh bersifat terbuka yang artinya pembelajaran yang diselenggarakan secara fleksibel dalam hal penyampaian, pemilihan dan program studi, waktu penyelesaian program, jalur dan jenis pendidikan tanpa batas usia, tahun ijazah, latar belakang 18 bidang studi, masa registrasi, tempat dan cara belajar, serta masa evaluasi hasil belajar (Kamayanthy, 2020).

\section{METODE}

Penelitian ini merupakan penelitian deskriptif kualitatif. Menurut Moleong dalam (Willy, 2020) bahwa penelitian kualitatif adalah prosedur penelitian yang menghasilkan data deskriptif berupa kata-kata tertulis atau lisan dari orang-orang dan perilaku yang dapat diamati. Selanjutnya, menurut Nazir dalam (Willy, 2020) metode deskriptif merupakan suatu metode dalam meneliti status sekelompok manusia, suatu objek, suatu set kondisi, suatu sistem pemikiran ataupun suatu kelas peristiwa pada masa sekarang. Metode yang digunakan adalah dengan menyebar angket di WhatsApp grup juga email.

Angket yang disebar berupa angket tertutup dan terbuka karena mereka atau responden harus memberikan alasan ketika memilih jawabannya. Responden adalah mahasiswa semester pertama angkatan 2020-2021 Program Studi Pendidikan Bahasa Jepang Unesa terdampak pandemik yang sedang mengikuti perkuliahan. Responden belum pernah mengikuti pembelajaran jarak jauh atau daring. Pengumpulan data dengan menyusun dan penyebaran angket pertanyaan-pertanyaan terkait dengan kegiatan pembelajaran daring. Data berupa hasil jawaban dari angket yang disebar. Daftar pertanyaan terdapat di tabel 1 berupa pernyataan yang diajukan ke responden berjumlah 39 mahasiswa. 
Tabel 1. Daftar pernyataan yang diajukan ke responden

\begin{tabular}{ll}
\hline Obyek & \multicolumn{1}{c}{ Pernyataan } \\
\hline 1. Perkuliahan secara daring memberatkan \\
2. Sinyal internet masih menjadi kendala terbesar, \\
3. Belum menguasai IT dengan baik \\
4. Kesulitan mengikuti perkuliahan daring \\
5. Terkendala Pemadaman listrik \\
6. Bantuan kuota \\
7. Pembelajaran tetap berlangsung, \\
8. Pandemi segera berakhir \\
\hline
\end{tabular}

Langkah selanjutnya adalah membuat tabulasi data yang merujuk pada hasil angket yang telah disebar sebelumnya, kemudian didapatkan jawabannya. Berikutnya, dilakukan analisis metode kualitatif deskriptif untuk mendapatkan gambaran kegiatan pembelajaran secara daring.

\section{HASIL DAN PEMBAHASAN}

Hasil penelitian yang telah diolah dengan tabulasi data terdapat pada tabel 2 berupa pernyatan dan respon angket yang telah diajukan ke responden melalui WhatsApp grup dan email.

Tabel 2. Daftar Pernyatan dan Respon Pernyataan

\begin{tabular}{lll}
\hline No & \multicolumn{1}{c}{ Pernyataan } & \multicolumn{1}{c}{ Respon } \\
\hline 1 & Perkuliahan secara daring & $53,84 \%$ responden menyatakan sangat setuju, kemudian \\
& memberatkan & $38,45 \%$ menyatakan setuju, dan tidak setuju sebanyak \\
& & $7,70 \%$ \\
\hline 2 & Sinyal internet masih menjadi & $66,66 \%$ responden menyatakan sangat setuju, 28,20 \\
& kendala terbesar & menyatakan setuju, $2 \%$ menyatakan tidak setuju \\
& & \\
\hline 3 & Belum menguasai IT dengan baik & $69 \%$ responden menyatakan sangat setuju, \\
& & $19 \%$ menyatakan setuju, $7 \%$ menyatakan tidak setuju, \\
& & $4 \%$ menyatakan sangat tidak setuju \\
\hline 4 & Kesulitan mengikuti perkuliahan & $66,66 \%$ responden menyatakan sangat setuju, 33,33\% \\
& daring & menyatakan tidak setuju \\
\hline 5 & Terkendala Pemadaman listrik & $64,10 \%$ responden menyatakan sangat setuju, $10,25 \%$, \\
& & menyatakan setuju, sedangkan 25,65\% menyatakan \\
& & tidak setuju \\
\hline 6 & Bantuan kuota & $76,90 \%$ menyatakan sangat setuju, menyatakan setuju \\
& & $23,0 \%$ \\
\hline 7 & Pembelajaran tetap berlangsung, & $69 \%$ responden menyatakan sangat setuju, 31\% \\
& & menyatakan setuju \\
\hline 8 & Pandemi segera berakhir & $89,74 \%$ responden menyatakan sangat setuju, $7,67 \%$ \\
& & menyatakan setuju, sedangkan 2,56\% menyatakan \\
& & sangat tidak setuju \\
\hline & &
\end{tabular}


Hasil penelitian menunjukkan bahwa pembelajaran daring di masa pandemi Prodi Pendidikan Jepang FBS-Unesa mempunyai beberapa tantangan, harapan, dan juga mengharapkan sebuah solusi.

\section{Tantangan Peserta Didik Selama Daring}

Menurut Kamus Besar Bahasa Indonesia bahwa kata tantangan adalah hal atau obyek yang menggunggah tekad untuk meningkatkan kemampuan mengatasi masalah atau rangsangan atau untuk bekerja lebih giat (Sugiyono, 2017) beberapa tantangan yang dihadapi diantaranya pernyataan nomor satu. Pernyataan perkuliahan secara daring memberatkan, $53,84 \%$ menyatakan sangat setuju alasannya kuliah daring lebih menitik beratkan pada tugas daripada interaksi antara dosen dengan mahasiswanya, juga tugas-tugas yg tiada henti, 38,45\% yang mejawab setuju beralasan bahwa mereka merasa keberatan dari segi sinyal yang sangat mengganggu serta tingginya pemakaian kuota sedangkan $8 \%$ yang menyatakan tidak setuju beralasan bahwa mata terasa sakit karena menatap layar laptop terlalu lama.

Pada penyataan 2, sinyal internet masih menjadi kendala terbesar responden yang menyatakan sangat setuju ada $72 \%$ alasannya sinyal tidak bisa dipastikan baik buruknya cuaca, apalagi kalau hujan untuk mahasiswa yang ada di luar daerah Surabaya. Sinyal yang kurang memadai sangat menghambat kegiatan pembelajaran, yang menyatakan setuju $28,20 \%$ dengan alasan sinyal terkadang tiba-tiba hilang sehingga memutuskan koneksi dan tidak bisa mendengar suara dosen, karena cuaca, hujan, sinyal sering hilang, kurang bagus, dan jaringan tidak stabil. Sebanyak $2 \%$ tidak setuju beralasan karena kendala terbesarnya adalah uang untuk membeli kuota internet.

Pernyataan 3 adalah belum menguasai IT dengan baik dengan $69 \%$ yang menjawab sangat setuju yang memiliki alasan masih gaptek, laptop terlalu jadul sehingga tidak bisa membuka aplikasi, laptop sering ngehang, dan baru menguasai beberapa aplikasi saja. Kemudian yang menyatakan setuju 19\%, memberikan alasan bahwa sudah menguasai IT meskipun masih setengah-setengah. Ada pula yang menjawab tidak setuju $7 \%$ dengan jawaban sudah bisa mengoperasikan IT dengan bantuan internet, cukup menguasai, sedangkan yang menjawab sangat tidak setuju sebanyak $4 \%$ dan beralasan sudah menguasai IT sejak SMA dan sudah bisa mengoperasikan berbagai aplikasi.

Pernyataan ke 4 adalah kesulitan mengikuti perkuliahan daring $66,66 \%$ responden menyatakan sangat setuju, dengan alasan jaringan tidak setabil, jaringan sering kesusahan, jaringan timbul tenggelam, koneksi internet yang buruk mengganggu proses pembelajaran, dan netral sinyal bukanlah kendala karena jaringannya selalu stabil bagi yang tinggal di kota. Selain itu, sebanyak 33, $33 \%$ menyatakan tidak setuju dengan alasan tidak merasa kesulitan dalam jaringan saat mengikuti perkuliahan.

Pernyataan ke 5 terkendala pemadaman listrik sering terjadi $64,10 \%$ responden menyatakan sangat setuju karena listrik mati secara mendadak dan tidak dapat di prediksi dan diantisipasi. Jadi, mau tidak mau bisa saja pembelajaran harus terputus di tengah jalan karena pemadaman. Disebabkan oleh seringnya padam, akibatnya mereka harus mengungsi ke rumah teman yang memiliki jaringan $\mathrm{Wi}$-Fi. Selanjutnya, $35,9 \%$ menyatakan tidak setuju dengan alasan sangat jarang ada pemadaman listrik, hanya terjadi sekali mati lampu, kadang kala listrik padam tiba-tiba yang disebabkan oleh korsleting.

\section{Harapan Peserta Didik Selama Daring}

Menurut Kamus besar Bahasa Indonesia kata harapan adalah sesuatu yang (dapat) diharapkan keinginan supaya menjadi kenyataan. Dalam mengikuti perkuliahan khususnya perkuliahan daring mahasiswa juga mempunyai harapan, seperti yang dinyatakan oleh tim penyusun KBBI harapan itu diharapkan supaya menjadi nyata untuk memfasilitasi jalannya perkuliahan. Oleh sebab itu, berikut adalah pernyataan harapan ditujukan bagi responden yaitu mahasiswa yang mengikuti perkuliahan daring di masa pandemi.

Pernyataan ke 6 berharap ada bantuan kuota, dengan perolehan sangat setuju sebanyak $77 \%$ berharap sekali bantuan kuota cair secara merata dan tepat waktu, dengan alas an membantu dalam mengikuti perkuliahan secara daring, untuk mengakses semua medsos dan semua aplikasi terkecuali game, dan tidak sanggup membeli kuota untuk mengikuti pembelajaran secara daring setiap hari. 
Sebanyak 23\% menyatakan setuju karena mengurangi biaya membeli kuota dan untuk berjaga-jaga jika $W i-F i$ rumah mati. Selain itu, menurut mereka kuota semakin mahal, terkadang ada tugas kuliah yang mengharuskan menonton Youtube, mengunggah karya di Instagram, belajar kebahasaan dari aplikasi online, dan lain sebagainya.

Dalam pernyataan ke 7 , pandemi segera berakhir, sebanyak $89,74 \%$ responden menyatakan sangat setuju, dengan alasan agar semua dapat kembali seperti semula, menjadi mahasiswa sesungguhnya karena virus sangat membuat orang susah. Selain itu, ingin sekali berkuliah dengan normal, kenal dengan temanteman secara offline, tidak hanya melalui layar hp/laptop dan kuliah daring kurang efektif . Sebanyak 7,67\% menyatakan setuju dengan alasan merasa kesusahan dalam menggunakan barang elektronik. Ada pula yang menyatakan sangat tidak setuju jika pandemic berakhir yaitu $2,56 \%$ dengan alasan senang berada terus di dalam rumah, tidak perlu bertemu dengan banyak orang, senang menggunakan masker karena identitas tertutupi, sangat tidak senang jika disentuh oleh orang lain (terutama saat bercanda dan saat berjabat tangan), dan merasa bahwa pandemi tidak akan pernah berakhir karena masyarakat sekitar mereka juga kurang disipilin dalam menerapkan protokol kesehatan.

Pernyataan ke 8 pembelajaran tetap berlangsung, pada pernyataan ini ada 69\% responden yang menyatakan sangat setuju. Alasannya, hal ini sudah menjadi kewajiban dalam berkuliah karena sudah membayar, sudah resmi menjadi mahasiswa, senang karena pertama kali jadi mahasiswa, dan supaya tidak tertinggal pengetahuannya. Sebanyak $31 \%$ menyatakan setuju dengan alasan diawasi orang tua dan menganggap keren mengikuti perkuliahan dalam jaringan.

\section{Solusi yang Diharapkan Peserta Didik Selama Daring}

Menurut Kamus Besar Bahasa Indonesia kata solusi adalah penyelesaian masalah, pemecahan masalah dan sebagainya serta jalan keluar. Di tengah-tengah pembelajaran daring yang diharapkan oleh mahasiswa atau responden yaitu adanya solusi agar pembelajaran tetap berjalan meskipun terdapat kekurangan di sana-sini ditengah-tengah berlangsungnya pandemi yang belum juga mereda, bahkan akhir-akhir ini semakin melonjak. Solusi kontiunitas seperti bantuan kuota yang diwacanakan selama ini. Dikatakan wacana karena ternyata di lapangan masih banyak mahasiswa yang belum menerima bantuan kuota. Memang, sudah ada yang menerima, tetapi nampaknya belum merata.

Oleh sebab itu, bantuan kuota sangat diharapkan sebagai solusi melancarkan perkuliahan. Angket terbuka yang disebarkan pada responden tentang solusi apa yang diharapkan dari pembelajaran daring ini sebagian besar mahasiswa atau responden menjawab dengan berharap sekali bantuan kuota yang diberikan secara merata kepada semua mahasiswa, karena selama ini ternyata tidak semua mahasiswa mendapatkan kuota, artinya ada yang tidak menerima bantuan tersebut. Mahasiwa berharap program tersebut dapat cair secara merata dan tepat waktu sehingga dapat membantu dalam mengikuti perkuliahan secara daring. Bantuan kuota diperlukan bukan hanya untuk mengikuti perkuliahan, tetapi juga digunakan untuk mengakses semua medsos dan semua aplikasi terkecuali game untuk memenuhi tugas-tugas dosen pengampu mata kuliah masing-masing.

Selain itu pemberdayaan baik pendidik maupun peserta didik sangat diharapkan yaitu dengan mengadakan pelatihan guna menambah wawasan guru berkaitan dengan PBM terutama di masa pandemi. Kemudian penggunaan aplikasi yang membantu peserta didik belajar dengan meminimalkan jaringan internet. Agar beban mereka tidak semakin besar di tengah pandemi seperti sekarang.

\section{SIMPULAN}

Berdasarkan angket yang disebar terhadap mahasiswa Program Studi Pendidikan Bahasa Jepang Universitas Negeri Surabaya disimpulkan bahwa 100\% mahasiswa Program Studi Pendidikan Bahasa Jepang menjalankan pembelajaran daring di semester ganjil tahun akademik 2020/2021. Mayoritas mahasiswa yaitu $78 \%$ menyatakan menghadapi tantangan terkait kuota agar pembelajaran secara daring dapat berjalan maka mereka berharap mendapatkan bantuan kuota. Hal ini lebih banyak disebabkan karena keterbatasan mahasiswa untuk menyediakan kuota internet secara terus menerus, pemahaman materi 
kurang maksimal, dan interaksi yang terbatas. Dari tantangan yang ada maka timbullah harapan bantuan secara merata. Jika bantuan cairnya merata, tantangan yang dihadapi mahasiswa akan terselesaikan. Selain tantangan dan harapan yang dihadapi mahasiswa maka

\section{DAFTAR PUSTAKA}

Alimuddin., T. D. M. 2015. Intensitas Penggunaan E-learning dalam menunjang Pembelajaran Mahasiswa Program Sarjana di Universitas Hasanuddin. http:// 95461-ID-intensitaspenggunaan-e-learningdalam-m, diakses 10 Februari 2020.

Anugrahana, A. 2020. "Hambatan, Solusi dan Harapan: Pembelajaran Daring Selama Masa Pandemi Covid-19 Oleh Guru Sekolah Dasar. Scholaria: Jurnal Pendidikan dan Kebudayaan, Vol. 10 No. 3, September 2020.

"Kamus Besar Bahasa Indonesia Daring." 2016. $K B B I$.

https://kbbi.kemdikbud.go.id/Beranda /TentangKami.

Kamayanthy, D. Y. 2020. Analisis Pembelajaran Menggunakan Edmodo pada Mata Pelajaran Kewirausahaan Kelas XII DPIB di SMKN 1 Majalengka Tahun Ajaran 2020-2021. . FKIP UNPAS.

Kemdikbud RI. 2020. Edaran Tentang Pencegahan Wabah COVID-19 di Lingkungan Satuan Pendidikan Seluruh Indonesia. Merdeka.com Kamis 12 Maret 2020 09:43.

Kementerian Dalam Negeri. 2020. Pedoman Umum Menghadapi Pandemi COVID-19 Bagi Pemerintah Daerah. 1-206. sebuah solusi juga diharapkan agar bantuan kuota segera terwujud nyata. Kemudian diharapkan adanya pemberdayaan bagi pengajar atau dosen maupun mahasiswa, dengan mengadakan pelatihan guna menambah wawasan guru berkaitan dengan PBM terutama di masa pandemi.

https://doi.org/10.1017/CBO9781107 $\underline{415324.004 .}$.

Kuntarto, E. 2017. Keefektifan Model Pembelajaran Daring dalam Perkuliahan dalam Perkuliahan Bahasa Indonesia di Perguruan Tinggi. Indonesian Language Education and Literature 3 (1), 99-100.

Permendikbud. 2013. Nomor 109. Ciri-ciri Pembelajaran Daring.

Sugiyono. 2017. Metode Penelitian Pendidikan. Pendekatan Kuantitatif, Kualitatif dan $R \& D$. Bandung: AlfaBeta.

Sulia, N. 2020. Persepsi Mahasiswa terhadap Pembelajaran Daring pada Masa Pandemi Covid-19. Universitas Baturaja: Ogan Komering Ulu.

Surahman, E. D. 2020. "Tantangan Pembelajaran Daring di Indonesia", . Journal of Islamic Education Management, Vol.5 No.2, Oktober 2020, Pascasarjana IAIN Palopo, Institut Agama Islam Negeri Palopo.

Willy, S. D. 2020. "Dampak Pandemi Covid-19 terhadap Kegiatan Pembelajaran Online di STMIK Komputama Majenang". Jurnal Teknologi dan Bisnis. Teknik Informatika STMIK Komputama Majenang. 